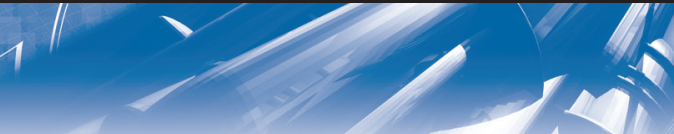

\title{
建築分野の複合現実感* \\ Mixed Reality in AEC Industry
}

\section{平沢岳人** \\ Gakuhito HIRASAWA}

Key words

Augmented/Mixed Reality (AR/MR), Architecture, Engineering and Construction (AEC), SfM,

SLAM, Building Information Modeling (BIM)

\section{1. は じめに}

私の研究室では，拡張現実感が話題になり始めた初期の 頃から建築学における応用研究を行ってきた。最も古い口 頭発表が 2006 年の建築学会大会のもので，研究そのもの に着手したのはその数年前なので, かれこれ一回りの年数 をかけて建築での実用を目的に適用範囲を徐々に広げてき た、いまではやや陳腐に思えるものも含まれるが，建築で の応用事例を幅広く紹介するのが本稿の努めであるので, 古くささを承知の上で紹介したい

\section{2. 室内（インテリア）で拡張現実感}

初期の研究では, インテリア (家具) のシミュレーショ ンに取り組んだ。住宅展示場をお借りして撮影し，希少性 の高いデザイナーチェアの 3D モデルを重畳して，シミュ レーションとしての複合現実感の有用性を確かめた（図 1).

インテリア・シミュレーションの場合, 撮影位置の選択 に融通が利くことが多く，比較的容易にリアリティを向上 させることができた.インテリア・シミュレータで特に問 題となったのは光学的な整合性で，写真が撮影された環境 に置かれたように仮想物をレンダリングして配置すれば, 良いシミュレーション結果が得られた。図 2 左は丸いテ

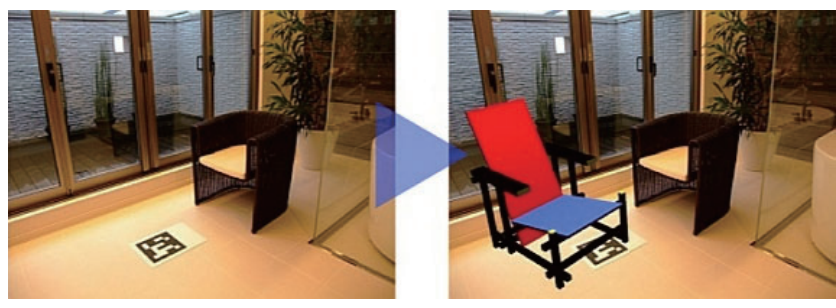

図 1 リートフェルトRed \& Blue で AR/MR

*原稿受付 平成 29 年 3 月 17 日

**葉大学大学院工学研究院（千葉市稲毛区弥生町 1-33)
ーブル，右はロングチェアがそれぞれ仮想物である。仮想 物は実寸でモデリングされており，その大きさが正しく再 現されるように重畳しているので，実際にその家具を自宅 に置いたらどのような雲囲気になるのか, 説得力のあるイ メージを得ることができた。このシミュレータを，およそ 100 点のデザイナーチェアの実大 3D モデルを用意して WEB アプリとして一般公開しアンケート調査を行ったと ころ，実用性に関しても良好な分析結果が得られた。

同じころ, 幾何学的な整合性を維持して仮想物を重畳で きるなら，写真に写った実物の大きさをかなりの精度で計 算できることに気付いた。文化財の修復現場では，コンベ ックスを当てて採寸した数值をスケッチと共に野帳に残す が，野帳に記録を残すことそのものにかなりの人手と時間 がかかり，また，丁寧さが欠ければ記録の不整合に後日悩 まされることが多々ある，拡張現実感に用いられるマーカ を写真に写し込んでおけば，採寸は研究室に戻ってからで よい. 当時のデジタルカメラで $\pm 0.5 \%$ 程度の精度が得ら れていたので，コンベックスの目盛りを読むのと変わらず 十分実用的であった。さらに，スケッチを描く必要もない ので，作業の効率が飛躍的に向上した。改修工事中だった 法華経寺五重塔（千葉県市川市）に一日だけ時間をいただ いて, 写真測量を行った。この時, 三次元モデルを CAD で入力する作業を並行して実施中であったので, 伝統木造 建築の部材間の複雑な継手仕口の整合性を CAD モデルで 検証するのに大いに役立った。図 3 に測量の様子を示す. 図 4 は, この時得られた正確な $3 \mathrm{D}$ デー夕を多軸加工機に

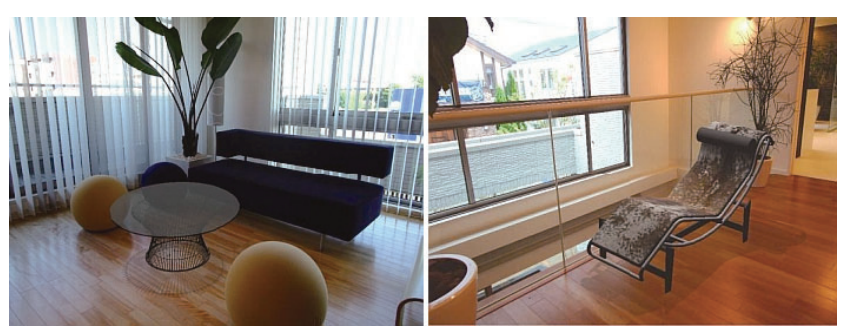

図 2 インテリア・シミュレータ 


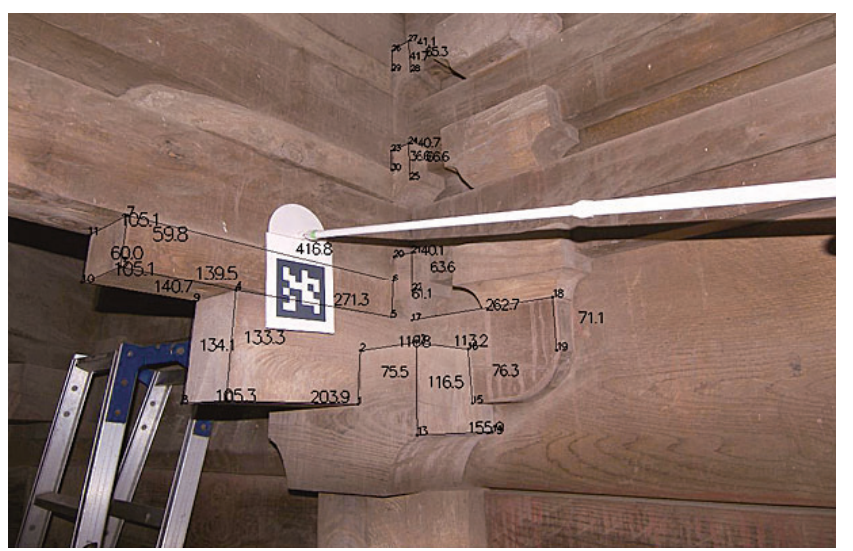

図 3 複合現実感を応用した採寸

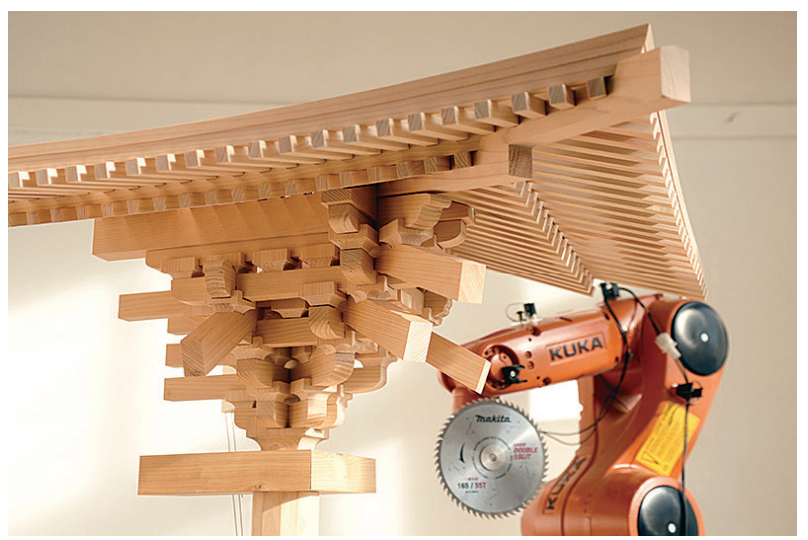

図 4 伝統木造建築の屋根隅部 $1 / 5$ スケール模型

入力することで作成した $1 / 5$ スケールの模型（木製）であ る。伝統木造建築の屋根隅部は最も複雑な部材の取り合い となり, 宮大工の一番の腕の見せ所であるが, 図 4 の精緻 なスケール模型を見るかぎり，この時の写真測量が実用的 な水準に達していることが分かる.

\section{3. 屋外空間での拡張現実感}

室内で一定の成果が得られたので, 次の段階は必然的に 屋外になる。建築学で屋外といえば, 街並みのシミュレー ションがまず思い浮かぶ。これを実施するに際し最も問題 となったのは，実物と仮想物の前後関係の整合性である. インテリアの場合は, カメラ位置（視点）の選択に融通性 があるが，屋外となると必ずしも都合の良い視点を選択で きない，視点から見て実物が仮想物の手前にあり，仮想物 の一部を遮蔽する場合が多くなる，欠けて見えない部分が きちんと見えないようにレンダリングしてから重畳しない と, オクルージョンが破綻する。これを解決するために, プロジェクションマッピングを用いることで, オクルージ ヨンを維持した，図 5 は, 模型での検証例であるが, 中 央部の黒いビルが仮想物で，手前のビル（実物）に遮蔽さ れた部分は描かれず，また，仮想物が落とす影を奥側のビ ル（実物）のファサード（壁面）と街路に正しく描画して

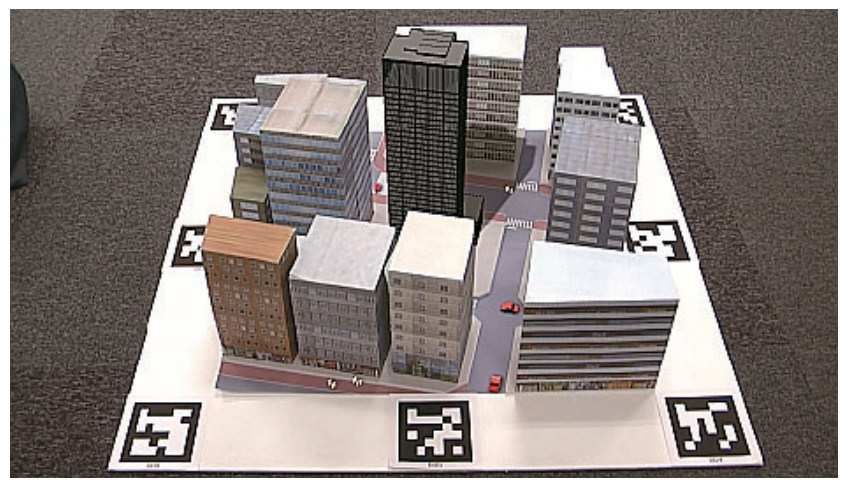

図 5 街並み模型での複合現実感

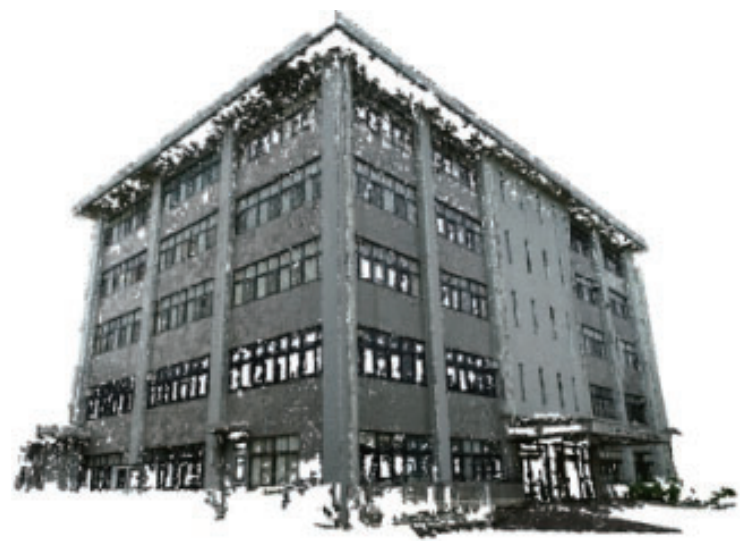

図 6 SfM によるポイントクラウドデータ

いる.

これで屋外での拡張現実感の実施に一応のめどがついた わけだが, 図 5 の例では, 実物の 3 次元モデルは模型作成 時に既に手元にあったので，プロジェクションマッピング を直ちに実行できた。実現場でのシミュレーションでは, 周囲の環境の $3 \mathrm{D}$ モデルを得ることがまず必要となり, こ れが大変難しかった. 当時話題になりつつあった, Structure from Motion（SfM）を用いることで，写真群か らポイントクラウドデータを得, そのデータをアルファシ エイプ法でサーフィス化したものを用いた。 ただし，この 方法で得られたサーフィスのデータは細かい凹凸があり, また，ノイズも多いので，オクルージョンキャストシャ ドウに適した形式にダウンサンプリングし領域抽出フィル 夕を通してからようやく実用的な周辺環境 3D モデルが得 られた。図 6 はポイントクラウドデータ, 図 7 はアルフ アシェイプ法によるサーフィス化の例, 図 8 が一連の処 理プロセスを示したものである。一瞥しただけではその意 味が分からない図 8 に示す一連の工夫は, レンダリング時 間をできるだけ短くして動画でも違和感のない重畳を可能 にするために不可欠な前処理だった。

ここまでの準備をした上で，ようやく図９の複合現実 感イメージを得ることができた。手前の夕イル張り外壁の 建物が実物で，奥のコンクリート打放しの建物が仮想物で 


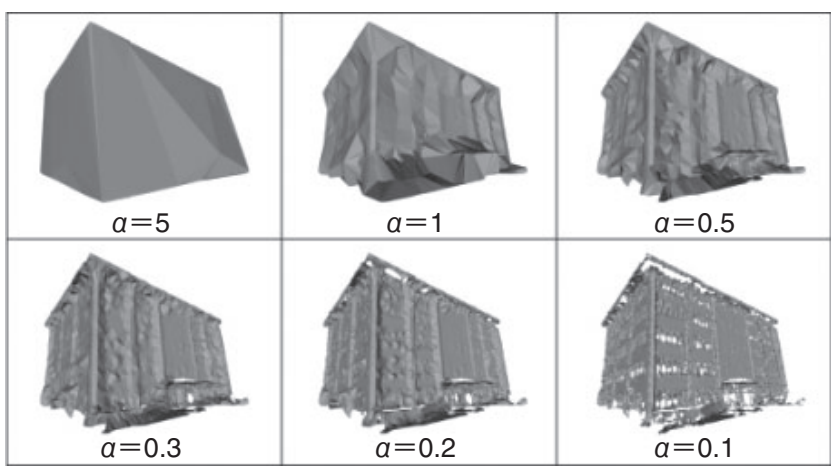

図 7 アルファシェイプ法によるサーフィス化

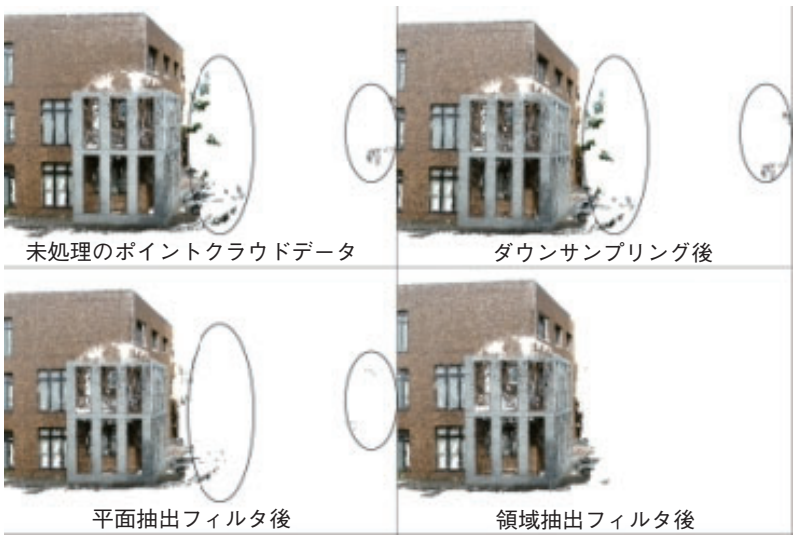

図 8 周辺環境 $3 \mathrm{D}$ モデルの構築手順

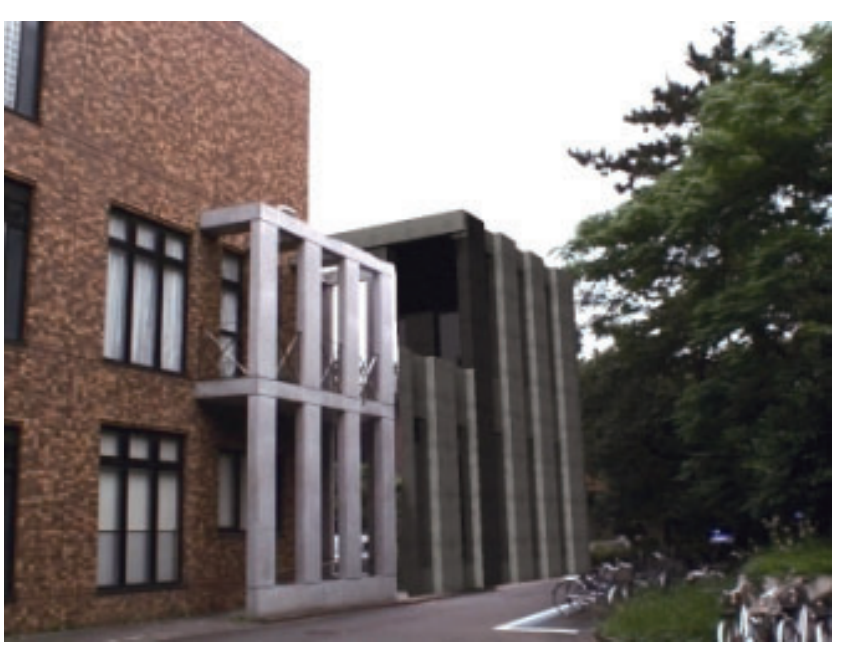

図 9 屋外の複合現実感によるシミュレーション

ある，実物に仮想物がきちんと遮蔽されているだけでな く，目を凝らすと実建築の右隅に付属する灰色のフレーム の隙間から仮想建築のファサード面の一部が透けて見え る.

建築実務者が納得するシミュレーションとしては，オク ルージョンの維持は極めて重要で，これの整合性を保つの にこれだけの手間がかかることが，建築での複合現実感の

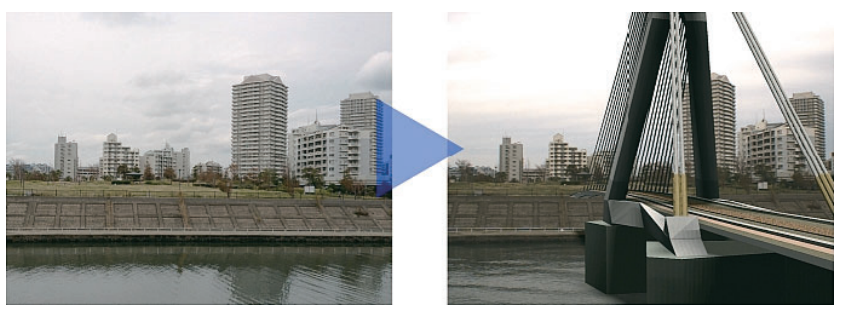

図 10 運河に橋を架けるシミュレーション

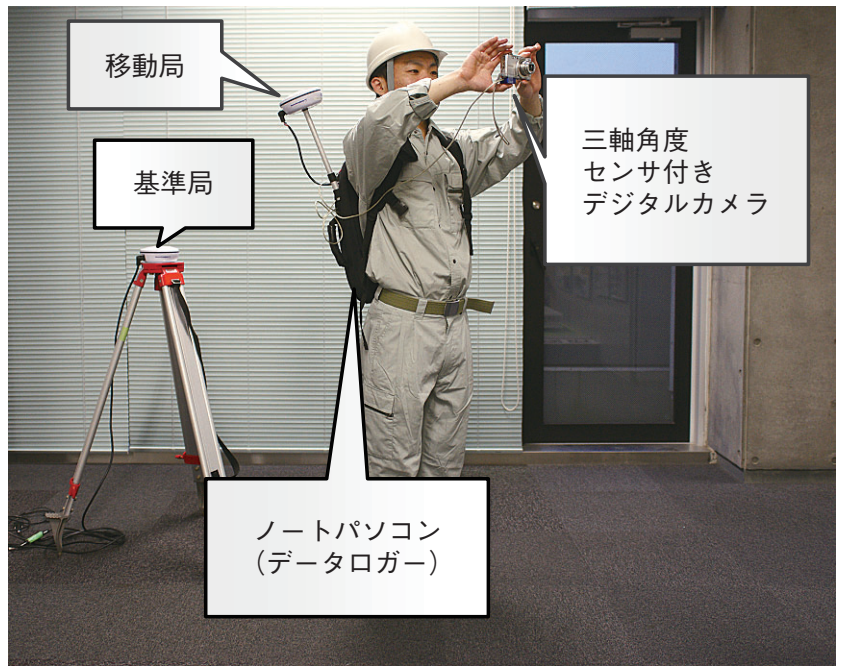

図 11 屋外での拡張現実感の必要装備

活用の障壁の一つになっていると思われる.

もう一つの障壁は, 図 1,3 に写り达んでいる 2 次元バ ーコードのようなビジュアルマーカが, 屋外ではたいてい の場合使えないことである。マーカを使わないで，カメラ 位置・方向を推定しなければならない。この問題を解決す るにはいくつかの方法があり，現代ではもう少し洗練され た方法もあり得るが，センサ類にほぼすべてを頼る直感的 な方法から試みた。

カメラ位置（緯度，経度，高度）を正確に知るために は, Real Time Kinematic-GPS (RTK-GPS) を使うこと で数センチの誤差で位置を得ることができる，次に，カメ ラのレンズが向かっている方向や傾きに関しては，いわゆ る姿勢センサ（3DOF Inertial Measurement Unit）から得 ることにした。二つのセンサから複合現実感の実行に必要 なカメラ位置・向きを得ることができた。簡単な例だが, 図 10 に運河に橋を架けた事例を示す。このように，土木 的なスケールのものを対象にしても拡張現実感を屋外で応 用することに成功した。

複合現実感が屋外で可能になったことは良いのだが, RTK-GPS では基地局と移動局の二つを同時に運用しなけ ればならないことや，七ンサ類のケーブルがかさばること など，とても軽装備とはいえない風体になってしまった。 図11は, ヘッドマウントディスプレイを装着していない からまだおとなしいぐらいで，これでは複合現実感を屋外 


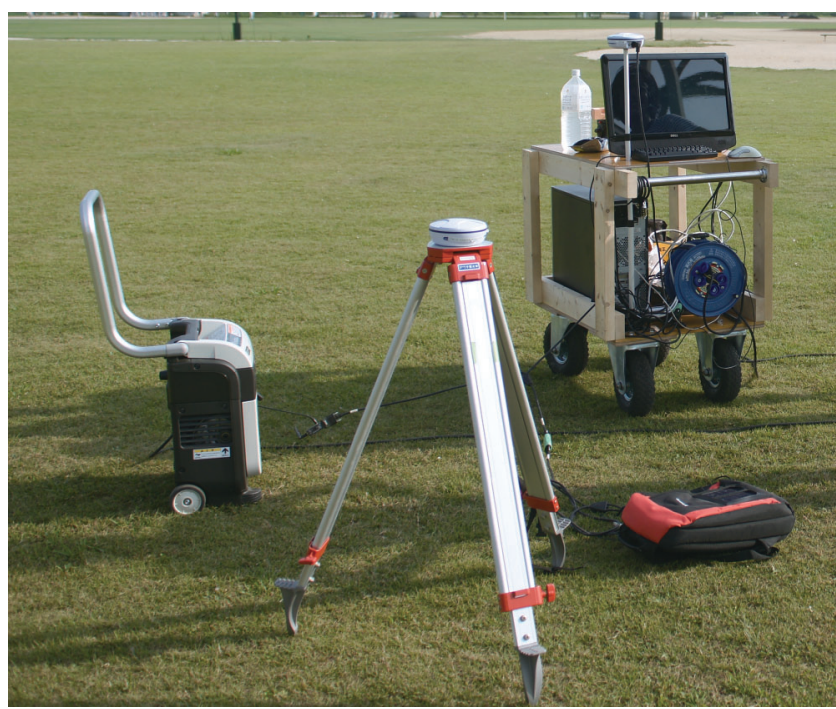

図 12 屋外拡張現実感実験の装置群（2012 年ごろ）

で積極的に活用しょうという気持ちにはなれないと思われ る.

大げさな装備のほかにも，この方法での複合現実感の実 行には技術的な問題があって, センサ類のジッター, 磁気 など試験環境からの影響, 長時間の使用によるドリフト誤 差の蓄積など, 何も対応策をとらないと, シミュレータと しての完成度が著しく損なわれてしまうことが分かった。 単純にカメラ位置・向きを求めただけでは不足であり, セ ンサ值の変動傾向を監視して静止状態の判定, 重力加速度 による姿勢の補正，テンプレートマッチングによる方位の 補正，ローパスフィル夕によるセンサ值変動の平滑化な ど，多くの処理を組み込んでようやく観賞に堪える複合現 実感による建築シミュレーションが実現した，当時のノー ト PCでは能力が足りず，デスクトップ PC が必要となっ たため，現場に発電機を持ち込んでの実験になってしまっ た，現代においては，当時と同程度のシミュレーションに 図 12 ほどの装備は不要と思われるが, 要求される解像度 もいまや $4 \mathrm{~K}$ となっているので, 高詳細な滑らかさを優先 するなら，現代でも似たような構成になってしまうのでは なかろうか

\section{4. 建築実務的な拡張現実感の活用}

筆者の専門は建築構法といって, 他分野の方には分かり にくいが，やや乱暴な説明をすると，建築物を部位・部材 に分割してその総体として建築を考える，そういう研究分 野である。意匠設計などに比べものづくりの現場に近く， 施工現場に関わる研究も行う。「2．室内での拡張現実感」 で紹介した写真測量もそういった研究の一環である。

施工管理では，設計（図面）ど扔りに施工されているか どうかの確認が重要な仕事の一つであり，土木分野では 「出来形検查」と固有の名称が与えられている．3D スキ ヤナや先述の SfM を応用したソフトウエアで点群を得て,

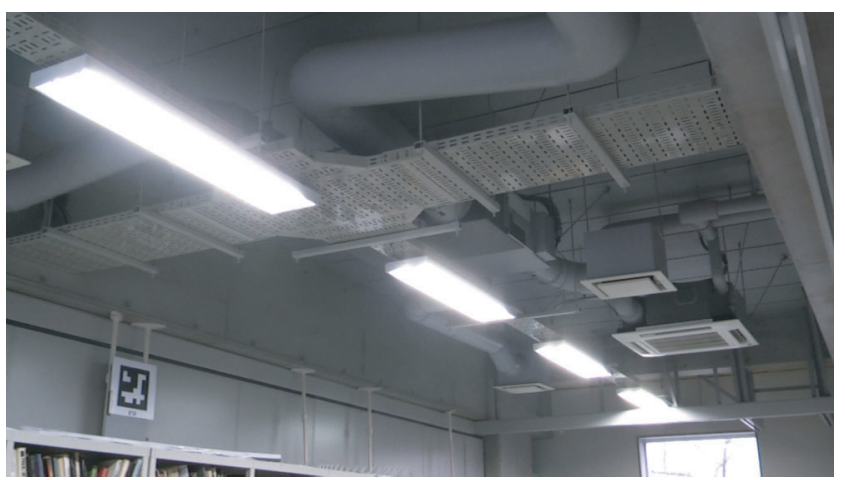

設計時の 3D データを重畳する

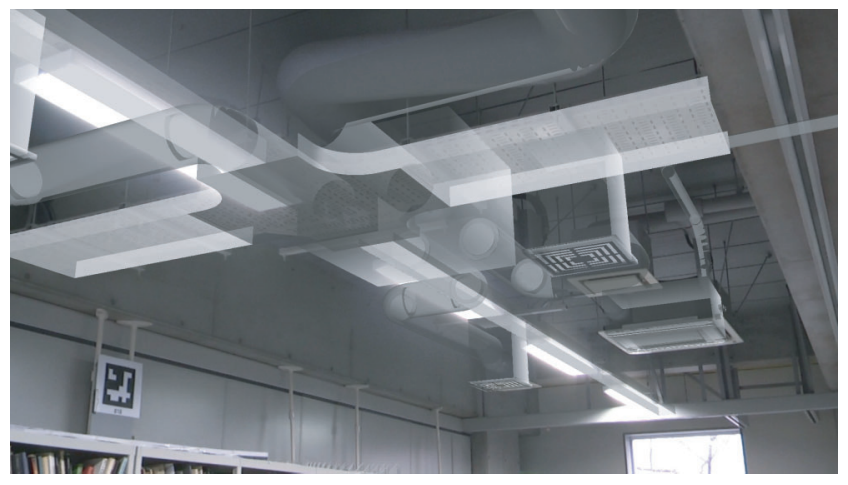

図 13 複合現実感による設備配管の検査

これを CAD 内部で設計の 3D モデルと重ね合わせて確認 する手法が用いられ始めている，マーカを設置できる場合 には，比較的簡単に 3D モデルを工事の現況に重畳して， 検查業務に応用できる。図13 はモノクロではやや見にく くなるが, オフィスビルの天井裏の設備配管に関して実際 の施工と設計時の 3D モデルを重畳して検査しているとこ ろである。部分部分を目で追いながら図面と順に照合して いくのに比べ，ひとまとめに効率よく検査できる.

マーカの有無で複合現実感の実行難易度が大きく違うこ とは先述のと扔りであるが, 施工現場を想定すると, 多数 のマーカの設置を管理業務に含めることは，理屈の上では 可能でも，管理コストの増大を招いてまで採用されること はないだろう。マーカなしでも品質管理に使える画像を容 易に取得できるなら図 13 の検査も実用化し得る。

建築では, 近頃 Building Information Modeling (BIM) と呼ばれる運動が推進されている，BIM とは，施工に取 り掛かる前に建物の精緻な $3 \mathrm{D}$ モデルを用意して，設計と 施工の品質を向上させようとするコンセプトである，仮に BIM のコンセプトが忠実に運用されるような環境が整え ば，複合現実感を応用した高度な施工管理が採用されるこ ともあり得る。カメラの位置と向きを得るために Simultaneous Localization and Mapping (SLAM) を用い る場合, ランドマークの取捨選択が重要になるが, BIM の3D モデルと施工の進渉管理データを照合すれば望まし い分離が実現するはずである。図 14 はこの発想で作成し たデモ動画のカットで，画像に写っている建築部位と仕上 


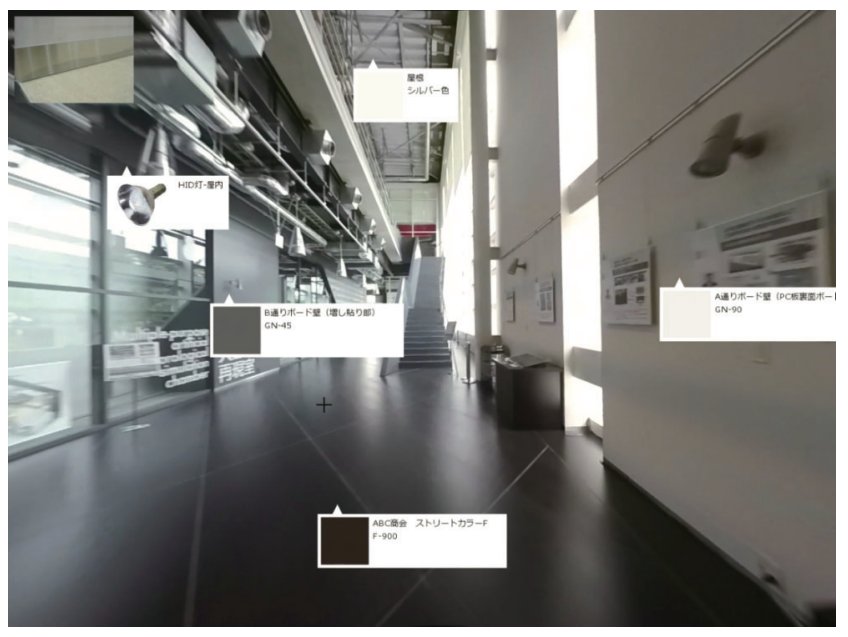

図 14 SLAM と BIM の複合現実感デモ

げ種別を，吹き出しの形で重畳している。このデモでは, SLAM の実行はあらかじめ済ませて動画の各フレームに カメラ情報を付加してあり，動画の再生時にBIM データ を照合してカメラの視体積内にある部材・部品の情報を選 択的に得ている。視線方向の深さ情報を利用することで, 壁の向こうの設備配管をレントゲン写真のように見せるこ とも可能である.

現状では，これら二つの処理をリアルタイムで同期的に 実行するには至っていないが，これらの統合そのものには さほど手間はかからないだろう。一方で，管理業務に使え るような精度の良いSLAM の実行に不可欠な BIM コンセ プトの運用そのものが難しいため, このデモに示すような 検査手法は当面実用化しない。建築施工で設計変更は付き
物であるが，現場対応で施工してしまった変更を BIM デ ー夕に戻って反映させることは，もちろん本来はすべきで はあるが，しないからである。この検査方法のほかにも多 数の有益な管理手法が具体化し認知されれば, BIM コン セプトの忠実な実行のインセンティブにもなり得るが, 鶏 と卵の関係にもあり，機が熟すまでにはもう少し時間が必 要である。

\section{5.お わ に}

当研究室での研究活動を振り返りながら，建築分野にお ける複合現実感の利用に関して包括的に紹介した。

マーカありからマーカなしへと複合現実感の実装方法も 多様になってきているが，実務的な利活用を到達点にする ならば，トラッキングのアルゴリズムだけでは解決でき ず，運用時の約束事の徹底がソリューションとなることも ある. BIM コンセプトの普遍化も，その一つである，付 加価值の高い応用を提案することで，複合現実感の実務利 用を推し進めたい.

\section{参 考 文 献}

1）研究室 HP : http://www.hlab-arch.jp/

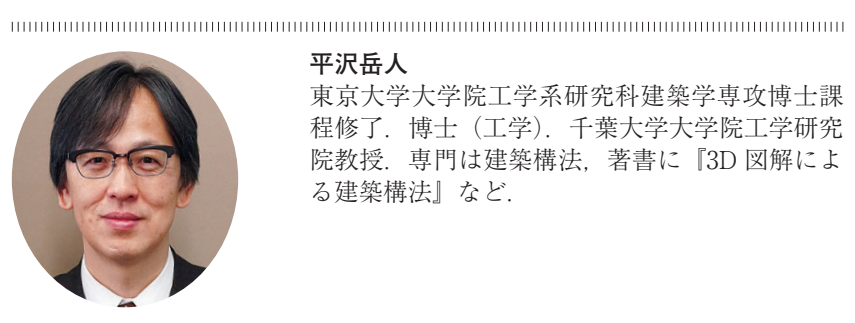

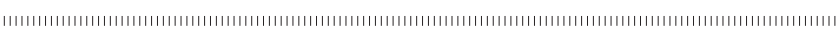

